\title{
The Gypsabee Dilemma
}

\section{Galina Trefil}

maria.trefil@gmail.com

Galina Trefil's short stories and articles have appeared in Neurology Now, Unbound Emagazine, The Guardian, Tikkun, Romea.CZ, Jewcy, Jewrotica, Telegram Magazine, Ink Drift Magazine, The Dissident Voice, and Open Road Review. Her fiction has been accepted in over sixty anthologies. She plans to release a new edition of her novel, The Incomplete Ones, regarding Romani slavery soon. 
Martina scowled, crumbled the note in one of her fists, and then folded her defiant arms across her chest. All that she wanted was to come to work, to do her job, and to collect her much-needed paycheck. She didn't need this aggravation right now. She really didn't. Unfortunately, it didn't seem like there was any alternative. She was going to have to call Michael out - either that or just suck up this latest dose of nastiness and stupidity.

Michael had a friendly, boisterous way about him that nearly everyone else here at the restaurant liked. He always had a joke to tell; always a performance to enact. In fact, even without these notes of his, it was the way that he never seemed to stop performing that had initially made Martina dislike him. What was he really, underneath that funny guy veneer? Maybe just a harmless buffoon, like everyone else seemed to think. Martina couldn't be sure. And, put to it, she didn't really care either. She just wanted the notes to stop. So she stormed up to him during the employee lunch break behind the seaside restaurant and, in front of a few of their co-workers, cut him off in the middle of one of his attention-grabbing diatribes.

"Michael." The way that she said his name came out not as an inquiry or a greeting, but more as an unsuccessful attempt to appear civil. "We need to talk."

He blinked, as though surprised that she was speaking to him at all. For some time now, she'd made clear that she wasn't a fan of his. Finally, he smirked, looked back at their co-workers, raised his eyebrows a few times, and then departed from the picnic table where they were eating. "Yes?" He purred when they were distanced enough for the others not to hear them.

"You've got to knock this crap off," she declared flatly, shoving the piece of paper into his hand.

"I don't get it," he replied, looking it over. "You're pissed off about this?"

"Oh, yes."

"Geesh, it was just a joke."

"A joke? Michael, you stole something and - "

"And what? I didn't steal anything from you. Look, the owner here knows me. We're friends. I borrowed a little from the cash register, sure, but I paid it back too. Either way, Martina, how's that any of your business?"

"You messing with the cash register is one thing and, if you've got something worked out with the boss, yeah, that's between the two of you. But what you wrote here isn't that you stole money. It's written that money was stolen period. And you signed it 'the Gypsies.” Her eyes narrowed bitterly. "The Gypsies, Michael? Really?"

He scratched his head. "I still don't get why you're upset."

"You don't get it?” She snapped. “Are you kidding me? I'm the only Romani employee here. Hell, I'm probably the only Romani person that a lot of the people that work here have ever knowingly met. Do you think that I need people giving me dirty looks, Michael? Do you think that, when I come to work, I want to have to deal with aspersions like this?"

"Oh, come on," he scoffed. "Everybody knows that I'm the one who wrote that note. I wouldn't frame you for stealing."

"No, but you're making a joke out of a stereotype that I have to live with every single day. I'm not a thief, Michael."

"I didn't say that you are." 
"No, not me personally. No, you'd never call me that - just my people as a general whole."

"I can't believe you're so worked up about this."

"And I can't believe that I have to actually dumb this down for you. If it were any other minority group and you were putting this kind of racism about at work, you'd be fired. Friendship with the boss or no friendship with the boss, you'd lose your job because this is discrimination. And don't think that I don't know that you've been doing this for a long time just because I haven't said anything before now. It's not okay to leave little racially-charged messages lying on tables or on the bathroom walls, Michael. Hell, what's your thing about Romani people anyway? Why are you so fixated on us? What gives you the right to call yourself one of us?"

"Look, you say you're Roma, but how do I really know that?"

"What?"

"Well...." His eyes ran over her in an invasive, almost appraising fashion. "How would I really know? I mean, there's nothing about you that really indicates you're a Gypsy."

"Oh, I'm sorry," she flared, her fists clenching, "did I forget my crystal ball, bandana, and gold hoops at home today? How very thoughtless of me. I can see how that would cause you to become confused. Just taking me at my word that this is my ethnic background, which I would incidentally appreciate to not be demeaned for in my work place, that's clearly too much to ask."

"What I mean is, my girlfriend is a Gypsy. And you can tell she's a Gypsy. I mean, it's really obvious."

"Huh?" Well, that was certainly an unforeseen twist. What self-respecting Romani girl would date this bozo, Martina questioned? Either a masochist or one seeking to inflict some serious misery on her parents, no doubt.

"Yeah, my girlfriend's a Gypsy and she thinks my notes are funny. She doesn't think there's anything wrong with them. She also doesn't have any problem with me calling myself a Gypsy. Maybe you just need to lighten up."

Martina took a moment to force her stunned, gaping jaw to close. "Michael McKay. You're Irish, yeah?”

He shrugged. "Sure, my family's got some Irish, if coming over here from Ireland a hundred years ago counts anyway."

"Well, Mr. McKay, how would you feel if I came to work and started tossing raw potatoes in with your lunch and calling you a 'Paddy?"' He burst out laughing. "Oh, sure. You think it's funny now, but if you deal with it long enough, you'd start to sing a different tune. That's how it is for me. I have to deal with constant bullcrap about my background. Constant jokes and pranks and...." He only laughed harder. "Man, you're an empathy-lacking jackass!" She spat. "Just try to have some consideration for other people's feelings, will you? Try to treat people with the same respect that you're given."

Michael only continued his loud guffawing. He strolled away, leaving her near-shaking with rage and a feeling that she had accomplished absolutely nothing.

The next day, there was another note left out, roughly to the tune of the last one. From across the room, Martina and Michael's eyes met. His gaze was mirthful as he baited her. In turn, she envisioned yanking his tonsils out through his nose.

All too aware that not one of them had deigned to call Michael out, Martina didn't feel right about joining her co-workers during the lunch break. Instead, she sat in the restaurant parking lot in her car, munching on a sandwich while she thumbed through a book on gems and minerals. Doing so reminded her that she wasn't going to be a waitress forever. No, she had her intentions set on a gemology school. Just a few more months of saving up for her tuition and she was out of here. She'd get her degree and then be working in the diamond trade, far away from Michael's repugnant sense of humor.... 
"Hi!" Martina looked up from her book, startled by the sudden knock on the hood of the car. Wow. That was her first thought. Just... wow. Even before the girl introduced herself, Martina knew, just knew, that this had to be Michael's girlfriend. She wore a low-cut peasant blouse, multiple clunky necklaces, large golden bangles, and a bright, flowing skirt. "I'm Flower," she announced, putting her hand forward through the open driver's window as a gesture of friendliness. Flower, eh? Why, yes, Martina couldn't help but nod. Of course, she had a name like that. "Michael told me that you and he had a little spat yesterday."

"That's one way to put it."

"I thought that maybe we could have a talk about it."

Martina stiffened, reluctantly closing her book and setting her sandwich aside. "Why?"

"Well, you know that he's just having some harmless fun, don't you? He wouldn't ever do or say something offensive."

"Actually, no, I don't know that. I'd say I was pretty clear with him that what he's doing is blatantly racist. And he's made it clear that he has no intention to stop, which only makes it more obvious that, that's exactly what he is."

"Oh, no," Flower protested. "You've got him all wrong."

"Do I?"

"Michael has total respect for Gypsies."

"Sure," Martina snorted. "Sure, he does. That's why he calls us 'Gypsies,' and not 'Roma.' That's why he calls us thieves, because he respects us so much."

"He doesn't mean 'thief' the way you're taking it. He means it in a...more...carefree way."

"A carefree way?"

"You know, how we Gypsies just don't believe in possessiveness, the same way that other people do. Objects come and go and, ultimately, belong to a lot of different people. They're nothing to get your panties in a twist over."

"Uh huh...." Martina glowered. "And exactly what is your background then, Flower? Because, I've got to tell you, by that Halloween-type get-up you're wearing, I'm going to go out on a limb and say that you're not actually Romani at all."

"My soul is Romani," Flower remarked, a degree of defensiveness kicking at her zen.

"Your soul?"

"I have been a Gypsy for many lifetimes."

"I see."

"During my last life, I was even sent to Auschwitz," Flower sighed woefully. "I was a Gypsy King's daughter.... So, believe me, I wouldn't be dating a guy who doesn't respect the Gypsy people."

"So, I'm in the presence of reincarnated royalty," Martina fumed, cocking her head to one side. "Hip hip hurray."

"I'm not lying."

"Not to me, perhaps," shrugged Martina. “To yourself though? Oh, yes. Very much indeed. Look, Flower, my great-grandparents died in Auschwitz and I feel pretty damn certain that you weren't being gassed alongside them. I get that you probably think that Roma are free-spirited and magical or whatever, but you can kindly take your romantic notions and shove them. All girls like to play dress up when they're little. When you become a grown up, you should know when to put the costume back in the closet though."

"Oh my gosh, you are so rude!" Flower gasped. 
"No, you're the one that's being rude by treating my heritage like it's some whimsical get-up that you can take on and off! You want to stand here, in front of someone whose family has been killed for being Roma, and spout out some twaddle that implies you'd have a damn thing to do with any of us if we were truly in the hotseat again? Give me a break!"

"I would!"

"Oh, really? Then if you're so dedicated to Romani culture and community, tell me about the school segregation our kids are facing in Eastern Europe. Tell me about the forced sterilizations Romani women have endured without compensation. Tell me about all of the other hate crimes and pogroms. No? You don't know about any of that stuff? Didn't think so.

'It's easy to say you're a reborn 'Gypsy' when you're surrounded by a bunch of dumbass hippies. It's a different thing entirely when that means belonging to a persecuted minority that's subjected to legitimate and intense violence. Go pull this crap in Eastern Europe. See what happens. Until then, get lost and take your sorry Esmeralda routine with you."

"Michael said you were a nasty person," Flower snapped. "I came here to try to show you that you were wrong about him. I was hoping that we might even all get to be friends."

Martina glared. "So, you'd have a real Romani girl as an accessary for this persona that you've created? Well, I guess that would've been novel, but I'm afraid that I'll leave you disappointed. Roma are people. We aren't props. We aren't caricatures."

"I didn't say that you were."

"You didn't have to," Martina scoffed. "Gypsabees never actually say what they're really thinking."

"Gypsabees?"

"Wannabe Gypsies. People like you," Martina clarified. "You all think that you have the right to define what we are with this... this... so-called 'Bohemian' crap. The real Romani experience is nothing like what any of you posers think it is and you damn sure couldn't handle what we actually have to live with, day in and day out. You'll never know how hard it is to deal with this kind of New Age stupidity and insensitivity."

Flower's eyes flicked downward to her costume, perhaps questioning its authenticity for the very first time, before she ultimately stormed away without another word.

Later that evening, as Martina lay studying in her bedroom, she was still scowling from the day's events. Gradually, she noticed that Michelle, her twelve-year-old sister, was poking her head through the nearby doorway. "Whatcha doing?" She purred.

"Homework."

"You aren't in school anymore."

“No, but I'm making sure that, when I am, I'll be one step ahead of everybody else. There's no point of getting a higher education if I'm not going to give it 100 percent. Either I do my best or I'll just stay waiting tables all my life, surrounded by jerks. No thank you!"

"Bad day?"

Martina raised a single eyebrow, then filled her in. Afterwards, Michelle frowned, plopping herself down on the bed beside her. "Why don't you just complain to your boss?"

"Honestly, I think I'm more likely to get punished than Michael if I make more of a to-do about this."

"Isn't that illegal or something? I mean, couldn't you sue? Claim it's a hostile work environment?"

Martina looked over at the middle-schooler, grinning for the first time in hours. "Whered you hear a phrase like that?" 
"Grandma likes me to watch daytime court shows with her." Michelle shrugged.

"Yeah, well, lawsuits happen a lot easier on TV than they do in real life. In real life, sadly, sometimes you just have to put up with this kind of crap."

"But... you can't just let them get away with this. It's racist and horrible."

"And, the older you get, the more racist, horrible people you'll meet. That's just how life works, kid. The one comfort that I have about the whole thing is that, I have zero doubt that, in ten years, I'm going to be sent around the world on gem-buying deals and those morons are still going to be washing dishes for minimum wage. Education, Michelle... more than anything else, it's the great equalizer. Those idiots want to demean us, make fun of us? Fine." Martina flipped the page of her book and returned to her reading. "They can choke on our dust when we reap the benefits of our labor."

"But it's not fair!"

Martina's gaze flicked up to her younger sibling's disappointed, bleak expression. She wanted to be a superhero for her. She wanted to wave a wand and make Michael and Flower and all the many like them reform their mean and thoughtless ways, so Michelle wouldn't find herself in similar circumstances when she entered the workforce. But that wasn't possible. And, really, there wasn't any use in sugarcoating reality. "If you don't like it," Martina finally told her, "then go do your own homework."

"What?"

"If you want to change the way things are, go be a lawyer. Go be a teacher. Go be a writer. All that starts with your homework."

Michelle lowered her eyes. "Work twice as hard as everybody else to get half the credit. That's what you mean, isn't it? Work harder... so that people have to pretend that they respect you?"

Martina was quiet for a moment. "What did great-grandpa and great-grandma do for a living?"

"They were photographers."

"Do you ever think of how hard that must have been? Just one generation back, our family were dirtpoor day-laborers in Czech Republic. The neighbors would as soon have spit on our family as tell them good day. But they worked hard and put together the only photography studio in the whole area. Imagine how much better their lives must have been. Maybe some people still couldn't get past the fact that they were Roma, but others... I bet that they just wanted to have their picture taken, by the only people who could take it. Great-grandpa and great-grandma fought to pull themselves up out of the muck, to put themselves in a position of power where they couldn't be stomped on anymore. We will too."

Michelle frowned. "But... our great-grandparents were still stomped on. Their studio was burned to the ground and they got killed in the Death Camp! In the end, all of their efforts didn't mean squat. What's the point of working so hard if, no matter what you do or where in the world you go, at the end of the day, you're going to be nothing but a worthless Gypsy?"

"You don't know what you're going to be. No one does."

"Tell that to the creeps at work."

"Hey!" Martina snapped. "People like that think that they get to define what Roma are. But they're wrong!" Martina held her book up in the air; then patted its cover. “This is who I am; what I am training myself to be. You hear? That's my choice and they can't take it from me.

"Every time that Roma get higher education, people like Michael and Flower fade more and more into the background. Give our people long enough and we'll make them go extinct."

"You really think so?"

"Yes," Martina nodded. "When you get down to it, what choice do we really have?" 